розробка проєкту навчання зі спеціальності (аналіз діяльності фахівця; розробка змісту професійної підготовки фахівця); розробка проєкту навчання з дисципліни чи теми (діагностика мети у процесі навчання; діагностика стану навчання; підготовка інформаційних матеріалів; добір навчальної літератури; розробка технологій навчання та контролю; планування освітнього процесу) [3, с. 37]. Отримання магістрантами заліку з дисципліни має відбуватися за результатами захисту розроблених дидактичних проєктів, а їхнє впровадження в реальний педагогічний процес підготовки бакалаврів-психологів повинно бути обов'язковою вимогою до проходження педагогічної (асистентської) практики (з відображенням та аналізом результатів у звітах із практики).

Висновки. Отже, нами було розроблено й обгрунтовано модель методичної компетентності майбутніх викладачів психології у процесі підготовки у ЗВО, реалізація якої має відбуватися на засадах компетентнісного підходу засобами дидактичного проєктування. Побудова методичної підготовки майбутніх викладачів психології на основі даної моделі забезпечить формування в магістрантів власного досвіду системного виконання типових завдань методичної діяльності викладача ЗВО і сприятиме становленню їхньої методичної компетентності у процесі навчання.

Подальші дослідження плануємо присвятити обгрунтуванню та розробці педагогічних умов формування методичної компетентності майбутніх викладачів психології у процесі підготовки у ЗВО на основі розробленої моделі.

\section{СПИСОК ВИКОРИСТАНОЇ ЛІТЕРАТУРИ}

1. Болотов В. А., Сериков В.В. Компетентностная модель: от идеи к образовательной программе. Педагогика. 2003. № 10. С. 8-14.
2. Гальперин П.Я. Введение в психологию. Москва : Книжный дом «Университет», 2006. 327 с.

3. Коваленко О. Е., Брюханова Н. О., Корольова Н. В., Шматков С. В. Методика професійного навчання. Харків : ВПП «Контраст», 2008. 488 с.

4. Ніколаєв О. М., Рубаняк Л. А. Методична компетентність як одна із основних складових професіоналізму майбутнього вчителя фізики. Збірник наукових праць Кам'янець-Подільського національного університету ім. Івана Огієнка. Серія «Педагогічна». 2016. Вип. 22. С. 99-102.

5. Про освіту : Закон України від 05 верес. 2017 р. № 2145-VIII. URL: https://zakon.rada.gov.ua/laws/show/ 2145-19\#Техt (дата звернення: 23.07.2020).

6. Родигіна I. Компетентнісно спрямований педагогічний процес. URL: http://osvita.ua/school/ theory/1963 (дата звернення: 23.07.2020).

7. Татур Ю. Г. Компетентностный подход в описании результатов и проектировании стандартов высшего профессионального образования. Материаль ко второму заседанию методологического семинара: авторская версия. Москва : Исследовательский центр проблем качества подготовки специалистов, 2004. $16 \mathrm{c}$.

8. Фесенко О. С. Дослідження феномена «професійна компетентність» вчителя у науковій літературі. Вісник Черкаського університету. Серія «Педагогічні науки». 2015. Вип. № 32 (365). С. 128-133.

9. Ціпан Т. С. Професійна компетентність сучасного вчителя. Інноватика у вихованні. Рівне, 2016. Вип. 3. С. 174-181.

10. Якубовски М. А. Математическое моделирование профессиональной деятельности учителя : монография. Львов : Евросвит, 2003. С. 102-105.

Дата надходження до редакиї: 26.07.2020 p.

Ярослав СЛУЦьКИй, кандидат педагогічних наук, завідувач навчально-методичним кабінетом Донбаського державного коледжу технологій та управління, м. Торецьк Донецької області

\title{
ЗАГАЛЬНІ ВИМОГИ ДО ОСВІТНЬОЇ ПРОГРАМИ СОЦАЛЬНО-ПЕДАГОГІЧНОГО СУПРОВОДУ ІНОЗЕМНИХ СТУДЕНТІВ
}

У статті розглянуто основні вимоги до освітньої програми, щчо використовується при проведенні адаптаційних заходів з іноземними студентами. У ході здійсненого дослідження надано характеристику фундаментальним положенням, наявність яких є важливою умовою для створення програми сочіально-педагогічного супроводу, як-от: необхідність формування в іноземних студентів відповідних теоретичних знань та практичного досвіду для можливості вирішення сочіальних і академічних проблем, щзо виникають при акультуращії; базування теоретичного комплексу програми на основі реальних практичних проблем, які в повсякденній діяльності іноземного студента стають перешкодою для соиіалізаціі; використання в основі програми сочіальнокультурних матеріалів, які сприяють ознайомленню 
з особливостями нової для іноземних студентів культури і принципів соиіальних взаємин; наявність у програмі чіткого плану адаптаиійної діяльності, з яким може ознайомитися іноземний студент для розуміння всієї системи проиесу супроводу, а також детального визначення як поняття і проявів, так $i$ способів боротьби з культурним шоком; надання іноземним студентам чітко вибудуваної стратегї̈ дій для вирішення адаптамійних проблем.

Ключові слова: іноземний студент, сочіальна та академічна діяльність, адаптачійний прочес, культурний шок, адаптаційна проблема.

B cтатье рассмотрены основные требования $\kappa$ образовательной программе при проведении адаптаиионных мероприятий с иностранными студентами. В ходе проведенного исследования охарактеризовань фундаментальные положения, наличие которых является важным условием при создании программы сочиально-педагогического сопровождения, среди которых: необходимость формирования у иностранных студентов соответствующих теоретических знаний и практического опыта для возможности решения возникающих при аккультуращии социальных и академических проблем; базирование теоретического комплекса программы на основе реальных практических проблем, которые при повседневной деятельности иностранного студента становятся препятствием для сочиализации; использование в основе программы социокультурных материалов, способствующих ознакомлению с особенностями новой для иностранных студентов культуры и принципов сочиальных отношений; наличие в программе четкого плана адаптачионной деятельности, с которым может ознакомиться иностранный студент для понимания всей системы прочесса сопровождения, а также детального определения как понятий и проявлений, так и способов борьбы с культурным шоком; предоставление иностранным студентам четко выстроенной стратегии действий для решения адаптационных проблем.

Ключевые слова: иностранный студент, социальная и академическая деятельность, адаптационный процесс, культурный шок, адаптационная проблема.

The article deals with the basic requirements for the educational program during the adaptation activities with foreign students. In the process of the research the characteristics of the fundamental conditions are given, the presence of which is necessary for the creation of the program of social-pedagogical support, among which: the importance of formation the appropriate theoretical knowledges and practical experience for foreign students to solve the social and academic problems arising in the acculturation process (the program should take into account all possible negative aspects of the process of adaptation and to put in the students' memory the theoretical experience of interaction with other cultures. Such experience will allow to the students to put into practice, in the necessary moment, the cultural patterns); the basing of the theoretical complex of the program on the basis of real practical problems that, in the process of a foreign student daily activities, become an obstacle for socialization (the socio-pedagogical support of a foreign student should be directed not only on the socio-cultural adaptation, but also on the development of the ability of academic interaction within the educational system. That's why on the first position comes such characteristics as: the understanding of the material by a student, without which the educational process is impossible, that leads us to realizing the need of communicative skills development; the, interaction between the teacher and classmates (this aspect includes both intra - and extracurricular activities of student)); the use of socio-cultural materials at the basis of the program, which contribute to familiarization with the features of the new, for the foreign students, culture and the principles of social relations (the social and pedagogical support of the foreign students should have two main ways - the preparation for academic activity and the preparation for daily activity. Thus, it is necessary to take a balance between these ways, which will prepare the individual for a full process of being in a new cultural environment); the presence of a clear plan of adaptation activities in the program, which can be familiarized by a foreign student for understanding the whole system of the accompanying process, as well as a detailed definition of both concepts and manifestations, and the ways to combat with cultural shock; the providing for foreign students a clear strategy for the adaptation problems solving.

Key words: foreign student, social and academic activity, adaptation process, culture shock, adaptation problem.

Постановка проблеми. За даними ЮНЕСКО, щороку все більша кількість людей стає іноземними студентами, тобто особистостями, які здобувають освіту в інших країнах [11]. Відповідно країни, які приймають таких студентів, мають забезпечити необхідний рівень їх адаптаційної підтримки, що дасть змогу як підвищити якісний рівень міжособистісного спілкування представників приймаючої держави з іноземними громадянами (які часто мають культурні відмінності), так і запобігти виникненню в іноземних студентів істотних проблем, викликаних культурним шоком.

Окреслені чинники демонструють важливість якісно побудованої системи соціально-педагогічного супроводу іноземного студента. Незважаючи на те, що наша держава не входить до переліку 20 країн із найбільшою присутністю іноземних студентів [12], вітчизняні заклади вищої освіти також повинні підвищувати рівень свого підготовчого навчально-методичного комплексу, одним із найбільш важливих елементів якого є освітня програма, на якій і грунтується процес супроводу іноземного студента. Тому ми впевнені в необхідності розгляду основних вимог до такої програми й ознайомлення 3 питаннями, що найбільш часто стають причиною зниження якості адаптаційного процесу.

Аналіз наукових досліджень і публікацій. Проблема адаптації особистості до нових для неї умов соціального плану розглядалася багатьма дослідниками. Так, Ю. Мірошниченко та А. Лобенко [7] досліджували вітчизняний і зарубіжний досвід адаптації членів колективу. Більш конкретизовано проблема вивчалася В. Овсянніковою [8], яка обгрунтувала саме питання психологічної адаптації. Водночас увага багатьох учених була спрямована на вивчення особливостей адаптації особистості в новому колективі (Б. Онопрійчук [9], I. Волкова [1], О. Гетьман [3] та ін.).

Дослідники також приділяли неабияку увагу організаційним питанням перебування іноземних студентів у ЗВО України (Б. Ковалюк [6], М. Гарасимчук, М. Пельчер [2] та ін.) та досліджували систему підготовки іноземних студентів в Україні (Т. Довгодько [4], Н. Зінонос [13]). Однак проблему щодо важливості та вимог до якості освітньої програми в цих роботах розкрито не було.

Цікавим є також дослідження Н. Зінонос та О. Вiхрової [5], в якому були розглянуті можливі елементи адаптації. Недоліком зазначеної роботи для нашого 
дослідження $€$ вузька спрямованість сфери пошуку вчених, що була присвячена адаптації до вивчення природничо-математичних дисциплін у закладах вищої освіти. Таким чином, результати, до яких прийшли вчені, не можуть бути повною мірою застосовані стосовно виокремленої нами проблеми - вимогам до програми підготовки іноземного студента в рамках системи адаптаційного супроводу.

Отже, проаналізувавши праці дослідників, ми можемо стверджувати про неабияку актуальність порушеної нами проблеми.

Мета статті - визначити основні вимоги до освітньої програми адаптаційного супроводу іноземних студентів.

Виклад основного матеріалу. Система соціально-педагогічного супроводу іноземних студентів $є$ важливою складовою адаптації особистості до нового культурного та академічного середовища, тому повинна відповідати певним вимогам. Розробка програми супроводу передбачає врахування всіх особливостей, притаманних акультурації. Однак для розуміння якісного рівня програми соціально-педагогічного супроводу необхідно дати відповіді на основні запитання, які розглянемо нижче.

1. Чи надає підготовча освітня програма можливість формування у студентів необхідних знань $i$ досвіду для розв'язання проблем адаптаиії, які вони мають подолати? [10]. Зазначимо, що програма має враховувати всі можливі негативні моменти процесу адаптації і закласти в пам'яті студентів теоретичний досвід взаємодії з іншими культурами. Такий досвід дозволить студентам у необхідний момент застосувати сформовані культурні шаблони на практиці та, відповідно, не допустити утворення проблемних ситуацій як у міжкультурному, так і в академічному планах або мінімізувати їх негативний вплив.

2. Чи засновані підготовчі курси на реаліях академічних проблем, зокрема таких, як розуміння лекційного матеріалу, взаємодія з викладачем та одногрупниками, використання бібліотеки та ресурсів Інтернету для вивчення тем англійською мовою, розуміння сутності терміна «плагіат» $i$ способів недопущення його використання у своӥх роботах випадковим чином? [10]. Необхідно розуміти, що соціально-педагогічна підтримка іноземного студента має спрямовуватися не лише на соціокультурну адаптацію, але й на розвиток здатності академічно взаємодіяти в рамках освітньої системи. Так, академічні аспекти не завжди пов'язані з культурними засадами. Тому культурна адаптація не може бути параметром успішного академічного коригування особистості. Така освітня адаптація заснована на важливості отримання іноземним студентом якісної освіти для формування в нього статусу професіонала після закінчення коледжу або університету. Таким чином, на перший план виходять такі характеристики, як розуміння учнем навчального матеріалу (без чого неможливий освітній процес загалом), що приводить нас до усвідомлення необхідності розвитку комунікативних навичок; взаємодія 3 викладачем та одногрупниками (у цей аспект входить як внутрішньо-, так і позааудиторна діяльність студента, тобто проведення міжособистісного контакту поза академічною діяльністю); вміння користуватися доступними інформаційними засобами - від Інтернету до бібліотек - для успішного процесу навчання; уникнення у своїх практичних або наукових роботах такого аспекту, як плагіат і розуміння того, які дії необхідно здійснювати для запобігання проблем із плагіатом надалі тощо. Таким чином, аспект академічних проблем та загалом академічної адаптації також повинен враховуватися при розробці освітньої програми з підготовки іноземних студентів.

3. Чи включає навчальна програма контент, щчо враховує аспекти соціально-культурного плану з питань взаємодії з американиями, наприклад, розкриття видів взаємодї з одногрупниками, сусідами по кімнаті, викладачами, а також види взаємодій, з якими студент може мати справу за межами закладу освіти, як-от: під час відвідування медичного иентру, відкриття банківського рахунку, використання поштової системи, вибору тарифу для мобільного телефону, дзвінка в екстрені служби при надзвичайній ситуації? [10]. Необхідно наголосити, що соціально-педагогічний супровід іноземних студентів повинен характеризуватися двома основними напрямами - підготовкою до академічної та повсякденної діяльності. Академічний аспект стосується взаємодії 3 академічним середовищем (тобто з тими особами, які мають пряме відношення до освітнього процесу - від одногрупників до викладачів) та розглядався нами вище. Другим аспектом $є$ повсякденна діяльність, яка характеризується виконанням студентом повсякденних для людини дій, - від відвідування медичного центру до походу в магазин. Важливо розуміти, що перенесення уваги на окремий напрям не дозволить повноцінно адаптуватися до іншого, що призведе або до негативних наслідків академічного плану, або до проблем у виконанні повсякденних дій. Таким чином, необхідно дотримуватися балансу між цими напрямами, що дасть змогу підготувати індивіда до повноцінного процесу перебування в новому культурному середовищі. Отже, теоретичні та практичні елементи акультурації до взаємодії іноземного студента 3 новим для нього соціумом також досить важливо включити до освітньої програми.

4. Чи надає програма підготовки знання про проиес культурної адаптації і про те, як ідентифікувати емоційні симптоми культурного шоку? [10]. Насамперед зазначимо, що здійснення соціально-педагогічного супроводу передбачає, як уже згадувалося, наявність відповідної програми дій. Однак варто зауважити, що іноземний студент не повинен ставитися перед фактом щодо необхідності виконання тих чи інших завдань для якісного процесу адаптації. Він має право бути ознайомленим зі змістом програми і планом дій, яким будуть керуватися працівники консультаційного центру закладу освіти. Володіючи такими знаннями, студент зможе більш чітко зрозуміти сутність адаптаційних вимог і більш ефективно пройти період акультурації у зв'язку зі знанням загального плану дій.

Також при підготовці іноземного студента до адаптації важливим є пояснення суті поняття «культурний шок». Особистість повинна розуміти, що означене явище проявляється у зв'язку із взаємодією іноземного студента 3 новою культурою, яка має відмінні від його власної культури принципи та поведінкові норми, що може призвести до виникнення відчуття необхідності повернутися у звичну «культурну атмосферу», де соціокультурні особливості не будуть мати елементів контрасту. Поняття культурного шоку $\epsilon$ показником того, що іноземний студент прибув 3 іншого культурного простору, що має значні відмінні риси. У разі, якщо такий психологічний стан не піддати впливу соціально-педагогічного супроводу, успіх іноземного студента як в академічній, так і в повсякденній сферах матиме мінімальні передумови або ж буде неможливий загалом. 
Тому зазначимо, що культурний шок не є лише внутрішнім станом особистості, що негативно впливає на індивіда та ефективність його діяльності. Цей феномен являє собою набір емоційних складових, які під впливом культурного шоку набувають певної форми i здатності продукувати зовнішні прояви у вигляді вираження свого емоційного стану студентом. Таким чином, культурний шок (за умов відсутності соціально-педагогічної підтримки) сприяє виникненню й розвитку проблем емоційного, академічного, психологічного й соціального характеру. Тому іноземний студент повинен бути ознайомлений із ймовірними емоційними аспектами, які йому необхідно подолати в період акультурації. Водночас при здійсненні якісної соціально-педагогічної підтримки ефект культурного шоку, що природно, буде мати місце, однак його негативний вплив може бути зведений до мінімуму. Це свідчить про важливість знання студентом тих емоційних факторів, що $є$ проявами культурного шоку, тобто включення теоретичних відомостей про нього до освітньої програми підготовки. У такому випадку особистість буде чітко визначати, в якому стані вона зараз перебуває та які дії необхідно вчинити для мінімізації негативних наслідків.

5. Чи має програма конкретні стратегії, щзо можуть бути використані студентами за наявності проблем академічного характеру? [10]. Освітня програма процесу акультурації повинна включати в себе планування заходів щодо запобігання проблем академічного плану, що може включати консультаційні заходи з викладачами, відвідування навчальних центрів, можливість проходження підготовки в коледжі або університеті з інтенсивного курсу вивчення мови тощо. Таким чином, ми можемо зробити висновок, що освітню програму необхідно планувати не тільки для потенційного використання в навчальному форматі, а й ураховувати інші заходи, що відбуваються в період адаптаційного процесу.

6. Чи передбачає формування основ поведінковоі адаптаиії до університету або коледжу спостереження за взаємодією інших студентів? [10]. Програми, що використовуються закладами освіти для супроводу іноземних студентів, іноді передбачають спостереження, які проводяться представником іншої країни за поведінковими та культурними діями студентів приймаючої країни. Такі дії надають змогу отримати візуальну інформацію щодо соціокультурних особливостей країни навчання та виробити стратегію власних дій (спільно з консультантом). Тому вважаємо, що поведінкова адаптація також має бути представлена в освітній програмі 3 підготовки іноземного студента.

7. Чи ознайомлені студенти зі стратегіями, які можуть бути використані при культурному шоияі (наприклад, написання листів, ведення щоденника, проведення бесід, звернення за допомогою до консультаційного иентту або офісу по роботі з іноземними студентами)? [10]. Під час адаптаційного процесу особистість намагається вирішити багато психологічних, культурних, лінгвістичних та соціальних проблем. Однак освітня програма має запропонувати певний комплекс дій та заходів, що мінімізують негативний вплив культурного шоку. У зв'язку 3 цим питання щодо стратегій передбачає саме наявність теоретичного опису заходів, які за необхідності можуть бути застосованими безпосередньо на практиці.

Таким чином, розглянувши найбільш значущі питання освітньої програми соціально-педагогічного супроводу іноземних студентів, ми виокремлюємо такі вимоги до цього документа:
1) застосування заходів, які дають змогу сформувати в іноземного студента необхідні вміння та навички для можливості вирішення проблем у межах соціальної та академічної діяльності;

2) використання в підготовчих матеріалах шаблонів реальних проблемних ситуацій, які можуть виникнути у процесі міжкультурної взаємодії;

3) розробка консультаційних заходів з урахуванням роз'яснення культурних особливостей соціуму тієї країни, де проходять навчання іноземні студенти;

4) підготовка до подолання наслідків культурного шоку (включаючи інформування про його емоційно-психологічні симптоми та способи протидії).

Висновки. Отже, освітня програма повинна враховувати всі особливості акультураційної підготовки іноземного студента - від можливості самодіагностики культурного шоку до практичного застосування навичок подолання соціокультурних бар'єрів.

Зважаючи на те, що наше дослідження не $\epsilon$ вичерпним, подальші наукові розвідки плануємо присвятити: вивченню основних напрямів адаптаційної роботи з іноземними студентами, зокрема соціокультурного, лінгвістичного та психологічного; аналізу результатів практичного застосування різних версій освітніх адаптаційних програм тощо.

\section{СПИСОК ВИКОРИСТАНОЇ ЛІТЕРАТУРИ}

1. Волкова И. А. Адаптация персонала как способ формирования кадровой политики организации. Кониелт. 2017. № 1. C. 1-5. URL: http://e-koncept. $\mathrm{ru} / 2017 / 470001 . h t m$ (дата звернення: 05.05.2020).

2. Гарасимчук Н., Пельчер М. Особливості визнання документів про освіту іноземних громадян в Україні. Актуальні питання організації навчання іноземних студентів в Україні : матеріали IV Міжнар. наук.-метод. конф. (м. Тернопіль, 2-4 травня 2018 р.). Тернопіль : Тернопільський національний технічний університет імені Івана Пулюя, 2018. С. 23-24.

3. Гетьман О. О. Організаційні механізми підбору, найму та адаптації персоналу. Вісник Одеського національного університету. Економіка. 2014. Вип. 19 (2). С. 30-34.

4. Довгодько Т. Розвиток системи підготовки іноземних студентів в Україні. Вищуа освіта України. 2012. № 3. T. 2. С. 102-104.

5. Зінонос Н., Віхрова О. Адаптація студентів-іноземців до вивчення природничо-математичних дисциплін у закладах вищої освіти. Теорія та методика навчання фундаментальних дисциплін у вищій школі. 2019. Т. XIV. Вип. 1 (14) : спецвипуск «Монографія в журналі». 220 с.

6. Ковалюк Б. Організація набору та навчання іноземних студентів у Тернопільському національному технічному університеті імені Івана Пулюя. Актуальні питання організації навчання іноземних студентів в Україні : матеріали IV Міжнар. наук.-метод. конф. (м. Тернопіль, 2-4 травня 2018 р.). Тернопіль : Тернопільський національний технічний університет імені Івана Пулюя, 2018. С. 16-17.

7. Мирошниченко Ю. В. Адаптація персоналу: досвід зарубіжних та вітчизняних підприємств. Проблеми і перспективи розвитку підприємництва. 2015. № 1 (2). C. 27.

8. Овсяннікова В.В.Проблеми психологічної адаптації персоналу організації. Проблеми сучасної психології. 2013. № 2. С. 85-91. 
9. Оноприйчук Б. С. Основные цели и этапы адаптации персонала в организации. Социальные науки. 2014. № 1. С. 11.

10. Gebhard J. EFL learners studying abroad: Challenges and strategies. Asian EFL Journal. 2013. 15 (2). P. $155-182$.

11. Internationally mobile students, Global, 20112017. Migration Data Portal. URL: https://migration dataportal.org/themes/international-students (дата звернення: 10.05.2020).

12. Top 20 countries for international students. The Guardian. URL: https://www.theguardian.com/higher- -education-network/blog/2014/jul/17/top-20-countries-international-students (дата звернення: 07.05.2020).

13. Zinonos N. Prospects of Using the Augmented Reality for Training Foreign Students at the Preparatory Departments of Universities in Ukraine. Augmented Reality in Education : Proceedings of the 1st International Workshop (AREdu 2018), Kryvyi Rih, Ukraine, 2 October, 2018. P. 87-92. URL: http:// ceur-ws.org/Vol-2257/paper10.pdf (дата звернення: 05.05.2020).

Дата надходження до редакиї: 14.05.2020 p.
УДК 378.091.212:37:316.64

DOI: $10.37026 / 2520-6427-2020-103-3-97-100$

\section{Сергій ШАРОВ,}

кандидат педагогічних наук,

доцент кафедри української та зарубіжної літератури Мелітопольського державного педагогічного університету імені Богдана Хмельницького

\section{СТРУКТУРА ТА ЗМІСТ СОЦАЛЬНОЇ КОМПЕТЕНТНОСТІ СТУДЕНТІВ ПЕДАГОГІЧНОГО УНІВЕРСИТЕТУ}

У статті розглянуто та систематизовано різні підходи до визначення структури соиіальноїкомпетентності учнів та студентів. Здійснено аналіз структури $i$ змісту соиіальної компетентності студентів педагогічного університету, зокрема ї̈ окреслено як багатокомпонентну характеристику особистості, ше дозволяє комфортно взаємодіяти із соиіальним середовищем та уникати конфліктів. Схарактеризовано компоненти соиіальної компетентності, представлені низкою дослідників, доведено, щчо соиіальна компетентність студентів педагогічного університету має певні особливості у зв'язку зі специирічністю та унікальністю обраної професії. Зазначено, щзо соиіальна компетентність студентів педагогічного університету включає такі компоненти, як: когнітивно-ціннісний (наявність соиіальних уявлень, изіннісних орієнтацій); емоційно-мотиваційний (наявність мотивації на розвиток власної соиіальної компетентності); операційно-діяльнісний (володіння вміннями конструктивної взаємодї із зовнішнім середовищем); рефлексивний (здатність адекватно реагувати на виниклі сочіальні ситуаціï).

Ключові слова: суспільство, компетентність, соичіалізація, здобувачі вищої освіти, структура.

В статье рассмотреньл и систематизированы различные подходы к определению структуры сочииальной компетентности учашихся и студентов. Осуществлен анализ структуры и содержания соџиальной компетентности студентов педагогического университета, в частности она определена как многокомпонентная характеристика личности, позволяющая комфортно взаимодействовать с соичальной средой и избегать конфликтов. Охарактеризовань компоненты сочииальной компетентности, представленные рядом исследователей, доказано, что соииальная компетентность студентов педагогического университета имеет свои особенности вследствие специфики и уникальности выбранной профессии. Отмечено, что сочиальна компетентность студентов педагогического университета включает такие компоненты, как: когнитивно-иенностный (наличие социальных представлений, цзенностных ориентаицй); эмоционально-мотивационный (наличие мотивации на развитие собственной социальной компетентности); операционно-деятельностный (владение умениями конструктивного взаимодействия с внешней средой); рефлексивный (способность адекватно реагировать на возникиие социиальные ситуации).

Ключевые слова: общество, компетентность, сочииализация, студенты, структура.

In this article different approaches to determining the structure of social competence of students and students are considered and systematized. Also we analyze structure and content of social competence of students of pedagogical university. We must noticed that social competence is one of the major competences of the modern individual, who is responsible for the effective life in society and constructive interaction with different people, social groups and institutions. In article author gives definition of social competence, its importance for the development of personality. Author make conclusion that it is a multicomponent characteristic of a person, 